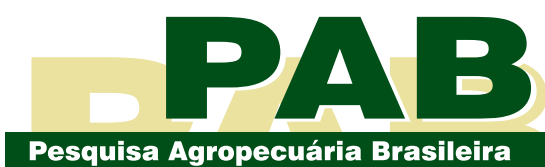

ISSN 1678-3921

Journal homepage: www.embrapa.br/pab

For manuscript submission and journal contents, access: www.scielo.br/pab

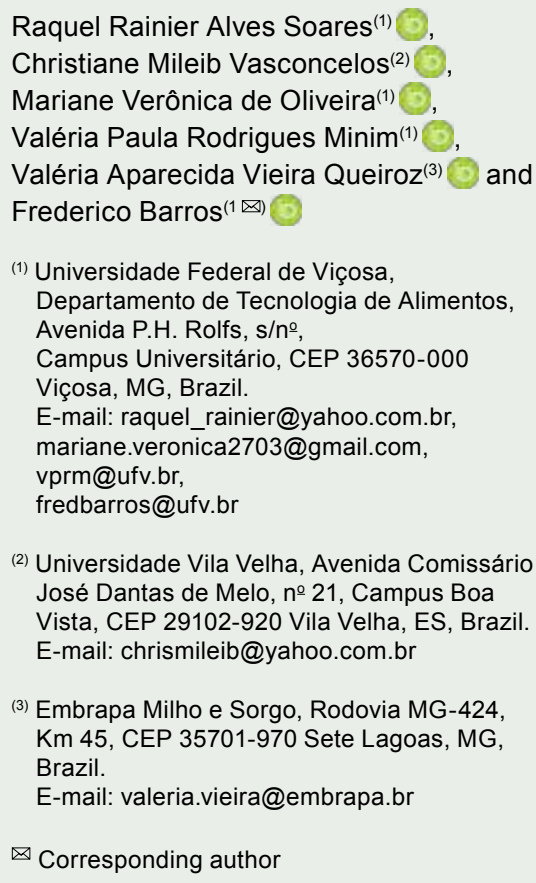

Raquel Rainier Alves Soares ${ }^{(1)}$, Christiane Mileib Vasconcelos ${ }^{(2)}$, Mariane Verônica de Oliveira ${ }^{(1)}$, Valéria Paula Rodrigues Minim ${ }^{(1)}$, Valéria Aparecida Vieira Queiroz ${ }^{(3)}$ and Frederico Barros $^{(1 \otimes)}($ ?

(1) Universidade Federal de Viçosa, Departamento de Tecnologia de Alimentos, Avenida P.H. Rolfs, $s / n$ Campus Universitário, CEP 36570-000 Viçosa, MG, Brazil.

E-mail: raquel_rainier@yahoo.com.br, mariane.veronica2703@gmail.com vprm@ufv.br fredbarros@ufv.br

(2) Universidade Vila Velha, Avenida Comissário José Dantas de Melo, № 21, Campus Boa Vista, CEP 29102-920 Vila Velha, ES, Brazil. E-mail: chrismileib@yahoo.com.br

(3) Embrapa Milho e Sorgo, Rodovia MG-424, Km 45, CEP 35701-970 Sete Lagoas, MG, Brazil.

E-mail: valeria.vieira@embrapa.br

$\bowtie$ Corresponding author

Received

December 21, 2018

Accepted

August 15, 2019

How to cite

SOARES, R.R.A.; VASCONCELOS, C.M.; OLIVEIRA, M.V. de; MINIM, V.P.R.; QUEIROZ, V.A.V.; BARROS, F. Starch digestibility and sensory acceptance of gluten-free foods prepared with tannin sorghum flour. Pesquisa Agropecuária Brasileira, v.54, e01205, 2019. DOI: https://doi.org/10.1590/S1678-3921. pab2019.v54.01205.
Food Technology/ Original Article

\section{Starch digestibility and sensory acceptance of gluten free foods prepared with tannin sorghum flour}

\begin{abstract}
The objective of this work was to develop gluten-free cookies and savory fried pies using tannin-rich sorghum (Sorghum bicolor) flour, to evaluate their in vitro starch digestibility, and to verify how knowledge of sorghum benefits may contribute to the sensory acceptability of both products. The contents of rapidly digestible starch, slowly digestible starch, and resistant starch were determined. Sensory acceptance was evaluated in two sessions: one without information on sorghum benefits to human health; and another where this information was presented. The resistant starch and slowly digestible starch contents of the cookies (5.07 and $16.22 \%$, respectively) were about twice those of the savory fried pies (2.54 and $8.89 \%$, respectively), whereas the opposite was observed for the rapidly digestible starch contents ( 9.89 and $19.65 \%$, respectively). The cookies and savory fried pies were sensorially accepted, with a significant increase in the means of the sensory scores after the information on sorghum benefits was disclosed. Therefore, gluten-free cookies and savory fried pies prepared with tannin sorghum flour have a great commercial potential, shown by the good sensory acceptance and by the slowly digestible starch and resistant starch contents of these products.
\end{abstract}

Index terms: Sorghum bicolor, cookies, human health, savory fried pies.

\section{Digestibilidade do amido e aceitação sensorial de alimentos sem glúten preparados com farinha de sorgo com taninos}

Resumo - O objetivo deste trabalho foi elaborar biscoitos tipo "cookies" sem glúten e pastéis com farinha de sorgo (Sorghum bicolor) rica em taninos, avaliar a digestibilidade in vitro de seus amidos e verificar como o conhecimento sobre os benefícios do sorgo pode contribuir para a aceitabilidade sensorial de ambos os produtos. Foram determinadas as concentrações de amido rapidamente digerível, amido lentamente digerível e amido resistente. A aceitação sensorial foi avaliada em duas sessões: uma sem informações sobre os benefícios do sorgo para a saúde humana; e outra em que essas informações foram divulgadas. As concentrações de amido resistente e de amido lentamente digerível dos biscoitos (5,07 e 16,22\%, respectivamente) foram aproximadamente o dobro daquelas dos pastéis $(2,54$ e 8,89\%, respectivamente), enquanto o oposto foi observado para a concentração de amido rapidamente digerível (9,89 e 19,65\%, respectivamente). Os biscoitos e os pastéis foram sensorialmente aceitos, com um aumento significativo nas médias dos escores sensoriais após a divulgação das informações sobre os benefícios do sorgo. Dessa forma, biscoitos tipo "cookies" sem glúten e pastéis preparados com farinha de sorgo contendo taninos apresentam grande potencial comercial, mostrado pela boa aceitação sensorial e pelas concentrações de amido lentamente digerível e amido resistente dos produtos.

Termos para indexação: Sorghum bicolor, biscoitos tipo "cookies", saúde humana, pastéis. 


\section{Introduction}

The consumption of sorghum [Sorghum bicolor (L.) Moench] in human nutrition has been mainly observed in the continents of Africa and Asia (Dicko et al., 2006). In the United States, this cereal has become increasingly popular within the food industry, also taking on a growing role in other economic sectors, such as livestock and ethanol production; as a result, sorghum can now be found in more than 350 product lines in the country (United Sorghum Checkoff Program, 2017). However, in Brazil, these uses are still incipient. A national research corporation that works with corn and sorghum, Embrapa Milho e Sorgo, has developed and evaluated sorghum-based products for human consumption, such as bakery products, cereal bars, pastas, functional beverages and others, which have had a positive acceptance in the celiac and nonceliac market (Queiroz et al., 2014).

Sorghum is gluten free and has the highest phenolic compound content among cereals (Awika \& Rooney, 2004; Pontieri et al., 2013). However, starch digestibility in sorghum is commonly lower due to starch accessibility restrictions caused by certain interactions with endosperm proteins (Rooney \& Pflugfelder, 1986) and with condensed tannins, known as proanthocyanidins (Barros et al., 2012). This low starch digestibility is noteworthy since it reduces sorghum nutritional value, negatively affecting its consumption (Wong et al., 2010). This same characteristic, however, also gives the cereal potential to prevent chronic diseases, such as diabetes, obesity, and cancer, whose risks are increased by the consumption of fast-digesting carbohydrates (Queiroz et al., 2011; Anunciação et al., 2018).

Some sorghum genotypes are also considered as potential sources of resistant starch (Teixeira et al., 2016). The resistant starch fraction is important due to its potential physiological benefits, since it represents a particular form of starch that is not digested until it reaches the human large intestine, where it is finally fermented by the intestinal microbiota, acting as a dietary fiber (Raigond et al., 2015). Similarly, the slowly digestible starch fraction presents a slow but complete hydrolysis in the small intestine. Its physiological advantages come from its property of sustaining and stabilizing blood glucose levels, both benefits related to diabetes control and satiety (Lehmann \& Robin, 2007; Zhang \& Hamaker, 2009). Several studies on nutrition have shown that the consumption of resistant starch and slowly digestible starch has the potential to promote hypoglycemic effects, prevent colorectal cancer, lower plasma cholesterol and triglyceride levels, inhibit fat accumulation, and improve vitamin and mineral absorption (De Deckere et al., 1995; Raigond et al., 2015; Wang et al., 2018).

Sorghum starch digestibility and bioactive compound content are affected by the used processing method. According to Cardoso et al. (2014, 2015), for example, the dry heat method preserves a higher concentration of antioxidants, such as phenolic compounds (e.g. tannins), when compared with the moist heat method.

The objective of this work was to develop glutenfree cookies and savory fried pies using tanninrich sorghum flour, to evaluate their in vitro starch digestibility, and to verify how knowledge of sorghum benefits may contribute to the sensory acceptability of both products.

\section{Materials and Methods}

The experiments were conducted at the Food Safety Laboratory at Embrapa Milho e Sorgo, located in the municipality of Sete Lagoas, in the state of Minas Gerais, Brazil, and at the Laboratory of Cereal Chemistry and Technology, at the Department of Food Technology of Universidade Federal de Viçosa, in the municipality of Viçosa, in the same state. The raw material used was the sorghum cultivar BRS 305 with a high tannin content. It was planted at the Embrapa Milho e Sorgo research station, located in the municipality of Nova Porteirinha, also in the state of Minas Gerais $\left(19^{\circ} 28^{\prime} \mathrm{S}, 44^{\circ} 15^{\prime} 08^{\prime \prime} \mathrm{W}\right.$, at $500 \mathrm{~m}$ altitude), in August 2015.

To obtain the flour used in the formulations of the gluten-free cookies and savory fried pies, sorghum grains were ground in a laboratory knife-hammer mill with a 1-mm sieve (WI 156-Brabender, Brabender GmbH \& Co. KG, Duisburg, Germany) and then stored in a cooling chamber at $-18^{\circ} \mathrm{C}$ until use. The total tannin content of the flour was determined according to Price et al. (1978).

The ready-to-eat products were analyzed for their in vitro starch digestibility and sensory acceptability in two different evaluation sessions: one without disclosing the information on sorghum benefits to human health; and the other presenting these benefits. 
The digestibility analyses were performed on both gluten-free products, in three replicates for each, following a completely randomized design. Sensorial analyses were conducted in a randomized complete block design, in which the judges were considered as blocks.

After several adjustments and testing of some formulations, the cookies were prepared by mixing the following ingredients, until the dough was formed: $117 \mathrm{~g}$ sorghum flour, $106 \mathrm{~g}$ corn starch, $90 \mathrm{~g}$ sucrose, $90 \mathrm{~g}$ margarine, $1 \mathrm{egg}$, and $20 \mathrm{~g}$ yeast. Flat disks of dough were baked in an electric oven, at $180^{\circ} \mathrm{C}$, for 10 min.

For the preparation of the savory fried pies, $500 \mathrm{~g}$ sorghum flour were cooked with $1 \mathrm{~L}$ water, adding $12.5 \mathrm{~mL}$ oil and $3 \mathrm{~g}$ salt, for $10 \mathrm{~min}$. After this mixture cooled down, the dough was rolled open on a table, which was previously sanitized and greased, and then cut into circles that were folded in half. The frying stage consisted of the immersion of these dough circles in hot soybean oil, at $180^{\circ} \mathrm{C}$, for $3 \mathrm{~min}$. For chemical analyses, the savory fried pies were produced without any filling; however, for sensory analyses, they were filled with ground beef.

Resistant starch content was determined according to the approved AACC method 32-40.01 (AACC, 2000) using the Resistant Starch Assay Kit (Megazyme International Ireland Ltd., Wicklow, Ireland).

The slowly and rapidly digestible starch contents were determined by the method proposed by Englyst et al. (1992), with some modifications: $200 \mathrm{U} \mathrm{mL}^{-1}$ $\alpha$-amylase and $55 \mathrm{U} \mathrm{mL}^{-1}$ amyloglucosidase were dissolved in $10 \mathrm{~mL}$ sodium acetate buffer $\left(0.1 \mathrm{~mol} \mathrm{~L}^{-1}\right.$, $4.0 \mathrm{mmol} \mathrm{L}^{-1} \mathrm{CaCl}_{2}, \mathrm{pH}$ 5.2) to hydrolyze $200 \mathrm{mg}$ of the sample in a water bath, at $37^{\circ} \mathrm{C}$, at an agitation speed of $170 \mathrm{rpm}$. The final contents were calculated on a dry basis and presented as percentage $\left(\mathrm{m} \mathrm{m}^{-1}\right)$.

Sixty-nine consumers, from both genders, were recruited among students and employees of Universidade Federal de Viçosa. There, the sensory evaluation was performed in individual booths, under white light, at the Sensory Analysis Laboratory of the Department of Food Science and Technology. The sorghum-based cookies and savory fried pies were served on disposable plastic dishes in a balanced and random order, in a monadic sequential presentation design.

Consumers received separate evaluation forms to register their acceptance of each product sample.
Regarding overall impression, the sensory acceptability of sorghum-based cookies and savory fried pies was evaluated using a 9-point hedonic scale, ranging from $1=$ "disliked extremely" to $9=$ "liked extremely" (Stone \& Sidel, 2004).

To determine the influence of non-sensorial characteristics on the consumer acceptance of sorghum-based cookies and savory fried pies, the samples were evaluated in two different sessions, with a three-day interval between them, according to the procedure described by Della Lucia et al. (2010) and Vidigal et al. (2011). In the first session, no information on sorghum characteristics and the benefits of its consumption to human health were presented (blind test); in the second, this information was disclosed (Figure 1).

Immediately after the second session, participants were asked to complete two questionnaires. The first one with data about their profile and socioeconomic status, including age, gender, marital status, family income, and level of education; and the second, with their sorghum consumption and overall consumption habits, answering questions such as: "What prevails at the time of the purchase?", "Have you heard of sorghum before?", "Do you know of or have ever consumed any product containing sorghum?", and "Do you eat cookies and/or savory fried pies often?". Participants were instructed before answering these questionnaires.

In the second session, consumers were also assessed regarding their purchase intention, using an evaluation form with a structured scale of 5 points, ranging from $1=$ "certainly would buy" to $5=$ "certainly would not buy" (Meilgaard et al., 1999).

To perform the sensory analysis, this research project was approved by the research ethics committee of Universidade Federal de Minas Gerais under Certificado de Apresentação para Apreciação Ética (CAAE), number 60844116.4.0000.5149. All participants agreed to the terms and signed the informed consent form.

In vitro starch digestibility analyses were conducted in three replicates, in duplicate. The t-test, at 5\% probability, was performed to check for any influences of the effects of different thermal treatments on both products, as well as on the contents of rapidly digestible starch, slowly digestible starch, and resistant starch. 
For the statistical analysis of the sensorial data, the F-test of the analysis of variance, at 5\% probability, was used to compare the scores of both products in the same session, and the t-test, between both sessions.

Statistical analyses were performed through the SAS, version 9.2, software (SAS Institute Inc., Cary, NC, USA), licensed to Universidade Federal de Viçosa.

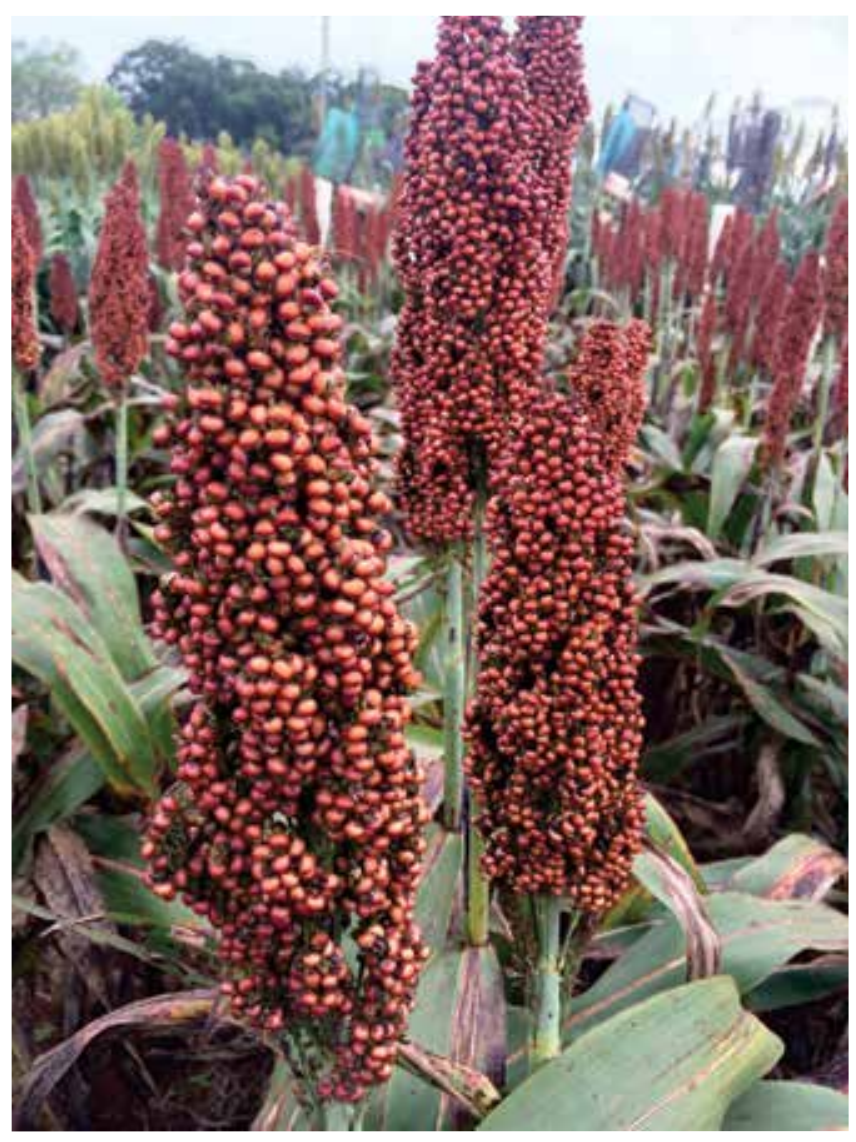

Sorghum is a cereal with a high nutritional value. Sorghumbased products are gluten-free and rich in fibers, which are known to improve the digestive system, avoiding cramping, bloating, and constipation. Researches have shown that high amounts of fibers in the body can help to reduce low-density lipoprotein (LDL), known as "bad" cholesterol, and cardiovascular diseases. Furthermore, the cereal is also rich in antioxidants, which eliminate free radicals, usually responsible for transforming healthy cells into carcinogenic cells. Sorghum consumption also helps to control glycemic levels, playing a benefic role in the monitoring of some chronic diseases, such as diabetes.

Figure 1. Informative text given to the consumers, explaining the benefits of sorghum (Sorghum bicolor) consumption, in the second session of the sensory acceptance test.
The sensorial scores were also evaluated by the internal preference mapping methodology (Macfie \& Thomson, 1988). The sensory analysis data was expressed as dispersion points for the samples and for each consumer in relation to the first two main components. The dispersion graph was obtained with the SensoMaker software (Pinheiro et al., 2013).

\section{Results and Discussion}

The total tannin content of the sorghum flour used in the product formulations was $57.16 \pm 2.54 \mathrm{mg}$ catechin equivalent per gram of sorghum flour.

The contents of resistant starch, slowly digestible starch, and rapidly digestible starch of the evaluated cookies and savory fried pies are presented in Table 1.

The resistant starch and slowly digestible starch contents were about twice as high in the cookies than in the savory fried pies, differing significantly between both products by the t-test. This was probably due to the fact that the cookies were produced with dry heat and their dough contained little water in its composition, differently from the savory fried pies whose dough, before being fried, was cooked in water, implying a greater starch gelatinization during processing. Comparatively, while evaluating the resistant starch contents of 49 sorghum genotypes, Teixeira et al. (2016) found that the BRS 305 cultivar, also used in the present study, had the second highest resistant

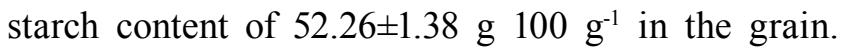
However, there was a slight decrease in this content

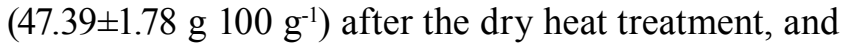

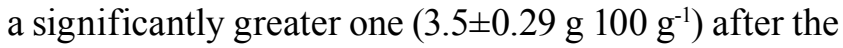
wet heat treatment.

Excess water and high temperature during processing contribute to starch gelatinization. However, the granular structure of starch can be maintained, as verified in some food products with low moisture contents, such as biscuits (Englyst et al., 2003). In the present study, the assessed cookies not only had a smaller amount of water in their formulation than the savory fried pies, but also lost much of their water due to evaporation when subjected to the dry heat treatment; therefore, there may have not been enough water for the occurrence of a more intense starch gelatinization, as observed in the fried pies. It should be noted that evaporation may also allow a greater proximity of water molecules. In the case of sorghum 
containing tannins, this procedure implies a greater possibility of tannin-starch interaction, forming nondigestible complexes, or even an intensification of existing interactions (Rooney \& Pflugfelder, 1986; Barros et al., 2012; Amoako \& Awika, 2019). These factors reduce the enzymatic susceptibility of starch to its hydrolysis and cause higher contents of resistant starch and/or slowly digestible starch.

In contrast, the savory fried pies presented twice the rapidly digestible starch content of the cookies, possibly because of the more severe heat treatment (cooking process followed by frying) they were subjected to and because they were in contact with an abundance of water, promoting a more pronounced starch gelatinization, as mentioned earlier. In addition, higher-intensity processing, including high temperature and high moisture contents, has a greater impact on starch gelatinization and on the structure of other starch-bound compounds, such as proteins. These compounds confer spatial hindrance and protect starch; however, after food processing, starch may no longer be strongly bound to such compounds and can then undergo hydrolysis and become rapidly digestible (Srichuwong et al., 2017; Vu et al., 2017).

Lemlioglu-Austin et al. (2012) found a direct relationship between the presence of phenolic compounds and the respective resistant starch contents in sorghum bran, as well as the glycemic index. The authors suggested that phenolic compounds have potential applications in the food industry to help reduce health problems related to type 2 diabetes and maintain a healthy body weight, due to their ability to reduce the starch hydrolysis rate, since high phenol contents resulted in a higher resistant starch content and in lower glycemic index levels.

The group of volunteers that participated in the sensory analysis, answering the questionnaires,

Table 1. Means and standard deviation of resistant starch (RS), slowly digestible starch (SDS), and rapidly digestible starch (RDS) contents of the cookies and savory fried pies made with tannin sorghum (Sorghum bicolor) flour ${ }^{(1)}$.

\begin{tabular}{lccc}
\hline Food & RS (\%) & SDS (\%) & RDS (\%) \\
\hline Cookie & $5.07 \pm 0.46$ & $16.02 \pm 0.87$ & $9.85 \pm 0.56$ \\
Savory fried pie & $2.33 \pm 0.59$ & $8.89 \pm 0.99$ & $17.59 \pm 2.85$ \\
t-test (p-value) & $<0.0001^{*}$ & $<0.0010^{*}$ & $<0.00010^{*}$ \\
\hline
\end{tabular}

${ }^{(1)}$ Results are expressed on a dry basis. *Significant by the t-test, in the same column, at $5 \%$ probability. consisted of 69 people: $61 \%$ were women, of which $71 \%$ were aged between 20 and 29 years; and $91 \%$ were students, of which $68 \%$ were still undergoing higher education. Only $5.8 \%$ of the volunteers were married, and the family income of $61 \%$ of the participants varied from $\mathrm{R} \$ 880.00$ to $\mathrm{R} \$ 2,640.00$.

According to the second questionnaire, in relation to the consumption of the evaluated products, 22, 26 , and $19 \%$ of the volunteers reported, respectively, consuming only cookies, only savory fried pies, or both of them frequently, which shows a certain expressiveness of these products in the daily habits of these consumers.

Furthermore, regarding the reasons for purchasing a product, pleasant taste was a highly relevant parameter for $92.8 \%$ of the consumers. This evidences that intrinsic factors of the product have greater importance in the consumption decision-making process than extrinsic factors, such as price and health benefits from food intake.

Among participants, 6\% reported some kind of food restriction, but none related to the ingredients used in the cookies and in the savory fried pies. Only $17 \%$ of the consumers knew of or had consumed food containing sorghum before. Moreover, only $17.4 \%$ of them had heard about sorghum before, which confirms that its diffusion in the Brazilian food market is still very restricted and that its nutritional, sensorial, and technological benefits need to be further promoted.

Both sorghum products obtained good sensory acceptance, although the cookies were significantly $(\mathrm{p} \leq 0.05)$ more accepted than the fried pies (Table 2). For the former, the average scores varied between "I moderately liked it" and "I liked it a lot", whereas, for the latter, between "I slightly liked it" and "I moderately liked it".

When the blind-test scores were compared with those of the test in which the information on sorghum health benefits was disclosed, there was an increase in the scores for both products, suggesting a positive influence of the provided information. The mean of the hedonic terms of both products also increased significantly $(\mathrm{p} \leq 0.05)$ (Table 2$)$.

The greater acceptance of cookies was also observed in the preference mapping (Figure 2), with the first and second main components explaining 60.05 and $25.97 \%$ of the variance, respectively, totaling $86.02 \%$, which was sufficient to discriminate between the products. It 
should be highlighted that the preference mapping was built for both sessions.

In the two sessions, the spatial separation in the preference mapping indicated the formation of three groups, with different acceptance profiles: group 1, cookies in the tests without and with the disclosure of information on sorghum benefits; group 2, fried pies in the test with this information; and group 3, fried pies in the test without it (Figure 2). The cookies located in the second and third quadrants were correlated with a higher concentration of consumers, being the most accepted. In session 1, a possible explanation for their greater acceptance is that they were baked rather than fried, and the consumers had no information on the components present in both formulations. In session 2, in which a greater number of consumers was evaluated, the positive influence of the presented information on the acceptance of the sorghum products was reinforced, confirming a certain tendency towards consumer concern with food quality, possibly linked to the prevention of noncommunicable chronic diseases, such as diabetes, obesity and cancer, due to the presence of antioxidants, resistant starch, and slowly digestible starch in the cookies and fried pies.

A purchase intention test was also performed in the second session of the acceptance test (Figure 3). A direct correlation was observed for the cookies and savory fried pies, which received averages of 4.2 and 3.6, respectively, on a 5-point scale, corresponding to "I would probably buy" and "I would certainly buy" for cookies, and "I am in doubt if I would buy" and "I would probably buy" for savory fried pies.

Analyzing the purchase intention scores individually, 82 and $58 \%$ of the consumers would have no doubts about acquiring sorghum cookies and savory fried

Table 2. Mean scores of cookies and savory fried pies, made with tannin sorghum (Sorghum bicolor) flour, compared between both sessions of the sensory acceptance tests, without (session 1) and with (session 2) the information about sorghum benefits, by the t-test, and in the same session, by the F-test.

\begin{tabular}{|c|c|c|c|}
\hline \multirow[t]{2}{*}{ Food } & \multicolumn{2}{|c|}{ Mean score } & \multirow{2}{*}{$\begin{array}{c}\mathrm{t} \text {-test } \\
\text { (p-value) }\end{array}$} \\
\hline & Session 1 & Session 2 & \\
\hline Cookie & $7.1 \pm 1.5$ & $7.7 \pm 1.3$ & $<0.0001^{*}$ \\
\hline Savory fried pie & $6.1 \pm 1.7$ & $6.9 \pm 1.6$ & $<0.0001 *$ \\
\hline F-test (p-value) & $0.0004 *$ & $0.0031 *$ & - \\
\hline
\end{tabular}

*Significant by the t-test, in the same row, or by the F-test, in the same column, at $5 \%$ probability. pies, respectively, based on the intrinsic (sensory) and extrinsic (disclosed information) characteristics of the two products (Figure 3).

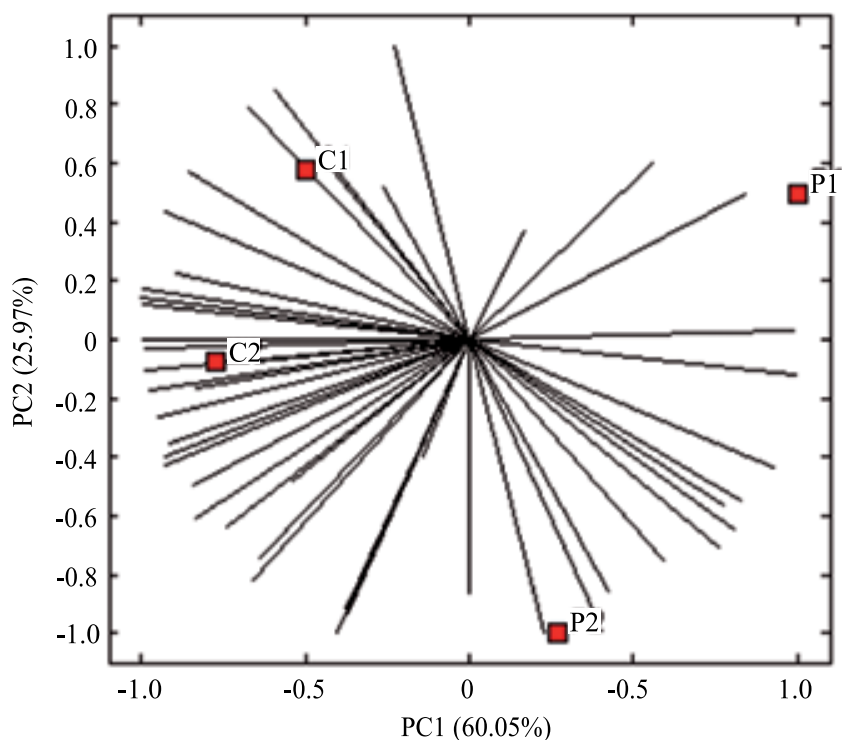

Figure 2. Preference mapping for the cookies (C) and savory fried pies (P) made with tannin sorghum (Sorghum bicolor) flour, evaluated in the test without (C1 and $\mathrm{P} 1)$ and with (C2 and P2) the disclosure of information on sorghum benefits.

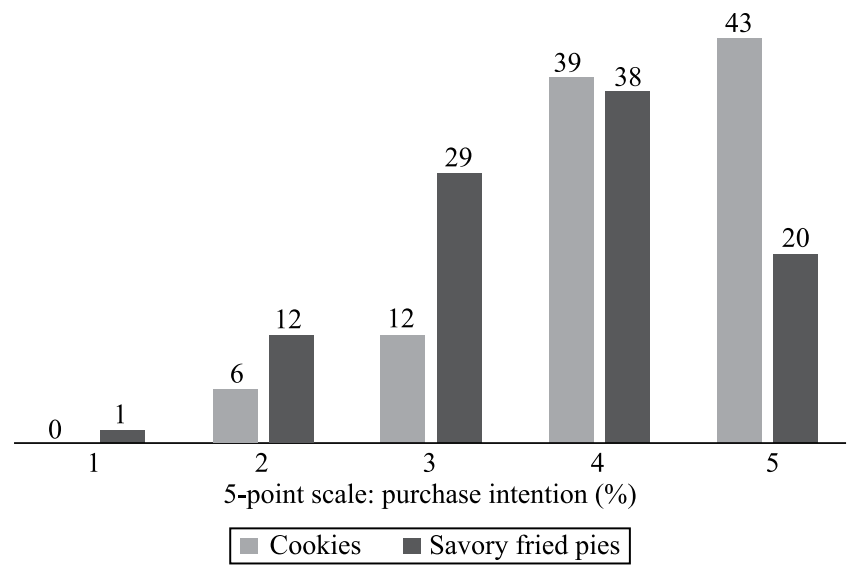

Figure 3. Purchase intention on a 5-point scale (ranging from $1=$ "certainly would buy" to $5=$ "certainly would not buy") for cookies and savory fried pies made with tannin sorghum (Sorghum bicolor) flour after the benefits of the consumption of this grain were presented in the second session of the sensory analysis. 
Therefore, the evaluated products are a good alternative when compared with other foods usually consumed. Moreover, the knowledge and dissemination of sorghum consumption and its benefits are relevant and positive factors for the consumer acceptance of the assessed sorghum-based products, and, therefore, should be encouraged.

\section{Conclusions}

1. The rapidly digestible starch, slowly digestible starch, and resistant starch contents of the evaluated cookies and savory fried pies prepared with tannin sorghum (Sorghum bicolor) flour are affected by the used processing method: wet heat, used in the production of the fried pies, drastically reduces the contents of resistant starch and slowly digestible starch, indicating that dry heat, used for the production of the cookies, is a better alternative for sorghum-based food processing.

2. Gluten-free cookies and savory fried pies prepared with tannin sorghum flour have a great commercial potential, shown by their good sensory acceptance, which improves significantly after the consumers are informed about the sorghum benefits to human health.

\section{Acknowledgments}

To Empresa Brasileira de Pesquisa Agropecuária (Embrapa), to Fundação de Amparo à Pesquisa do Estado de Minas Gerais (Fapemig), and to Conselho Nacional de Desenvolvimento Científico e Tecnológico (CNPq), for financial support.

\section{References}

AACC. American Association of Cereal Chemists. International Approved Method of Analysis. 11 ${ }^{\text {th }}$ ed. St. Paul: AACC, 2000.

AMOAKO, D.B.; AWIKA, J.M. Resistant starch formation through intrahelical V-complexes between polymeric proanthocyanidins and amylose. Food Chemistry, v.285, p.326-333, 2019. DOI: https://doi.org/10.1016/j.foodchem.2019.01.173.

ANUNCIAÇÃO, P.C.; CARDOSO, L. de M.; QUEIROZ, V.A.V.; MENEZES, C.B. de; CARVALHO, C.W.P. de; PINHEIROSANT'ANA, H.M.; ALFENAS, R. de C.G. Consumption of a drink containing extruded sorghum reduces glycaemic response of the subsequent meal. European Journal of Nutrition, v.57, p.251-257, 2018. DOI: https://doi.org/10.1007/s00394-016-1314-X.

AWIKA, J.M.; ROONEY, L.W. Sorghum phytochemicals and their potential impact on human health. Phytochemistry, v.65, p.11991221, 2004. DOI: https://doi.org/10.1016/j.phytochem.2004.04.001.
BARROS, F.; AWIKA, J.M.; ROONEY, L.W. Interaction of tannins and other sorghum phenolic compounds with starch and effects on in vitro starch digestibility. Journal of Agricultural and Food Chemistry, v.60, p.11609-11617, 2012. DOI: https://doi.org/10.1021/jf3034539.

CARDOSO, L. de M.; MONTINI, T.A; PINHEIRO, S.S.; PINHEIRO-SANT'ANA, H.M.; MARTINO, H.S.D.; MOREIRA, A.V.B. Effects of processing with dry heat and wet heat on the antioxidant profile of sorghum. Food Chemistry, v.152, p.210217, 2014. DOI: https://doi.org/10.1016/j.foodchem.2013.11.106.

CARDOSO, L. de M.; PINHEIRO, S.S.; CARVALHO, C.W.P. de; QUEIROZ, V.A.V.; MENEZES, C.B. de; MOREIRA, A.V.B.; BARROS, F.A.R. de; AWIKA, J.M.; MARTINO, H.S.D.; PINHEIRO-SANT'ANA, H.M. Phenolic compounds profile in sorghum processed by extrusion cooking and dry heat in a conventional oven. Journal of Cereal Science, v.65, p.220-226, 2015. DOI: https://doi.org/10.1016/j.jcs.2015.06.015.

DE DECKERE, E.A.M.; KLOOTS, W.J.; VAN AMELSVOORT, J.M.M. Both raw and retrograded starch decrease serum triacylglycerol concentration and fat accretion in the rat. British Journal of Nutrition, v.73, p.287-298, 1995. DOI: https://oi. org/10.1079/bjn19950030.

DELLA LUCIA, S.M.; MINIM, V.P.R.; SILVA, C.H.O.; MINIM, L.A.; CERESINO, E.B. Expectativas geradas pela marca sobre a aceitabilidade de cerveja: estudo da interação entre características não sensoriais e o comportamento do consumidor. Boletim do Centro de Pesquisa de Processamento de Alimentos, v.28, p.1124, 2010. DOI: https://doi.org/10.5380/cep.v28i1.17893.

DICKO, M.H.; GRUPPEN, H.; TRAORÉ, A.S.; VORAGEN, A.G.J.; VAN BERKEL, W.J.H. Sorghum grain as human food in Africa: relevance of content of starch and amylase activities. African Journal of Biotechnology, v.5, p.384-395, 2006.

ENGLYST, H.N.; KINGMAN, S.M.; CUMMINGS, J.H. Classification and measurement of nutritionally important starch fractions. European Journal of Clinical Nutrition, v.46, p.S33-S50, 1992. Suppl.2.

ENGLYST, K.N.; VINOY, S.; ENGLYST, H.N.; LANG, V. Glycaemic index of cereal products explained by their content of rapidly and slowly available glucose. British Journal of Nutrition, v.89, p.329-339, 2003. DOI: https://doi.org/10.1079/ BJN2002786

LEHMANN, U.; ROBIN, F. Slowly digestible starch - its structure and health implications: a review. Trends in Food Science and Technology, v.18, p.346-355, 2007. DOI: https://doi.org/10.1016/j. tifs.2007.02.009.

LEMLIOGLU-AUSTIN, D.; TURNER, N.D.; MCDONOUGH, C.M.; ROONEY, L.W. Effects of sorghum [Sorghum bicolor (L.) Moench] crude extracts on starch digestibility, estimated glycemic index (EGI), and resistant starch (RS) contents of porridges. Molecules, v.17, p.11124-11138, 2012. DOI: https://doi.org/10.3390/molecules170911124.

MACFIE, H.J.H.; THOMSON, D.M.H. Preference mapping and multidimensional scaling. In: PIGGOT, J.R. Sensory analysis of foods. $2^{\text {nd }}$ ed. New York: Elsevier Applied Science, 1988. p.381409 . 
MEILGAARD, M.; CIVILlE, G.V.; CARR, B.T. Sensory evaluation techniques. $3^{\text {rd }}$ ed. Boca Raton: CRC Press, 1999. 387p.

PINHEIRO, A.C.M.; NUNES, C.A.; VIETORIS, V. SensoMaker: a tool for sensorial characterization of food products. Ciência e Agrotecnologia, v.37, p.199-201, 2013. DOI: https://doi.org/10.1590/S1413-70542013000300001.

PONTIERI, P.; MAMONE, G.; DE CARO, S.; TUINSTRA, M.R.; ROEMER, E.; OKOT, J.; DE VITA, P.; FICCO, D.B.M.; ALIFANO, P.; PIGNONE, D.; MASSARDO, D.R.; DEL GIUDICE, L. Sorghum, a healthy and gluten-free food for celiac patients as demonstrated by genome, biochemical, and immunochemical analyses. Journal of Agricultural and Food Chemistry, v.61, p.2565-2571, 2013. DOI: https://doi.org/10.1021/ jf304882k.

PRICE, M.L.; VAN SCOYOC, S.; BUTLER, L.G. A critical evaluation of the vanillin reaction as an assay for tannin in sorghum grain. Journal of Agricultural and Food Chemistry, v.26, p.1214-1218, 1978. DOI: https://doi.org/10.1021/jf60219a031.

QUEIROZ, V.A.V.; MORAES, E.A.; MARTINO, H.S.D.; PAIVA, C.L.; MENEZES, C.B. de. Potencial do sorgo para uso na alimentação humana. Informe Agropecuário, v.35, p.7-12, 2014.

QUEIROZ, V.A.V.; MORAES, E.A.; SCHAFFERT, R.E.; MOREIRA, A.V.; RIBEIRO, S.M.R.; MARTINO, H.S.D. Potencial funcional e tecnologia de processamento do sorgo [Sorghum bicolor (L.) Moench], na alimentação humana. Revista Brasileira de Milho e Sorgo, v.10, p.180-195, 2011. DOI: https://doi.org/10.18512/1980-6477/rbms.v10n3p180-195.

RAIGOND, P.; EZEKIEL, R.; RAIGOND, B. Resistant starch in food: a review. Journal of the Science of Food and Agriculture, v.95, p.1968-1978, 2015. DOI: https://doi.org/10.1002/jsfa.6966.

ROONEY, L.W.; PFLUGFELDER, R.L. Factors affecting starch digestibility with special emphasis on sorghum and corn. Journal of Animal Science, v.63, p.1607-1623, 1986. DOI: https://doi.org/10.2527/jas1986.6351607x.

SRICHUWONG, S.; CURTI, D.; AUSTIN, S.; KING, R.; LAMOTHE, L.; GLORIA-HERNANDEZ, H. Physicochemical properties and starch digestibility of whole grain sorghums, millet, quinoa and amaranth flours, as affected by starch and nonstarch constituents. Food Chemistry, v.233, p.1-10, 2017. DOI: https://doi.org/10.1016/j.foodchem.2017.04.019.
STONE, H.; SIDEL, J.L. Sensory evaluation practices. $3^{\text {rd }}$ ed. New York: Elsevier, 2004. 408p.

TEIXEIRA, N. de C.; QUEIROZ, V.A.V.; ROCHA, M.C.; AMORIM, A.C.P.; SOARES, T.O.; MONTEIRO, M.A.M.; MENEZES, C.B. de; SCHAFFERT, R.E.; GARCIA, M.A.V.T.; JUNQUEIRA, R.G. Resistant starch content among several sorghum (Sorghum bicolor) genotypes and the effect of heat treatment on resistant starch retention in two genotypes. Food Chemistry, v.197, p.291-296, 2016. DOI: https://doi.org/10.1016/j. foodchem.2015.10.099.

UNITED SORGHUM CHECKOFF PROGRAM. All about sorghum. Available at: $<$ https://www.sorghumcheckoff.com/allabout-sorghum>. Accessed on: Oct. 172017.

VIDIGAL, M.C.T.R.; MINIM, V.P.R.; CARVALHO, N.B.; MILAGRES, M.P.; GOLÇALVES, A.C.A. Effect of a health claim on consumer acceptance of exotic Brazilian fruit juices: açaí (Euterpe oleracea Mart.), camu-camu (Myrciaria dubia), cajá (Spondias lutea L.) and umbu (Spondias tuberosa Arruda). Food Research International, v.44, p.1988-1996, 2011. DOI: https://doi.org/10.1016/j.foodres.2010.11.028.

VU, T.-H.; BEAN, S.; HSIEH, C.-F.; SHI, Y.-C. Changes in protein and starch digestibility in sorghum flour during heat-moisture treatments. Journal of the Science of Food and Agriculture, v.97, p.4770-4779, 2017. DOI: https://doi.org/10.1002/jsfa.8346.

WANG, Q.; WANG, P.; XIAO, Z. Resistant starch prevents tumorigenesis of dimethylhydrazine-induced colon tumors via regulation of an ER stress-mediated mitochondrial apoptosis pathway. International Journal of Molecular Medicine, v.41, p.1887-1898, 2018. DOI: https://doi.org/10.3892/ijmm.2018.3423.

WONG, J.H.; MARX, D.B.; WILSON, J.D.; BUCHANAN, B.B.; LEMAUX, P.G.; PEDERSEN, J.F. Principal component analysis and biochemical characterization of protein and starch reveal primary targets for improving sorghum grain. Plant Science, v.179, p.598-611, 2010. DOI: https://doi.org/10.1016/j. plantsci.2010.08.020.

ZHANG, G.; HAMAKER, B.R. Slowly digestible starch: concept, mechanism, and proposed extended glycemic index. Critical Reviews in Food Science and Nutrition, v.49, p.852-867, 2009. DOI: https://doi.org/10.1080/10408390903372466. 